\title{
Politics of Citizenship: Towards an Analytical Framework
}

\author{
Kristian Stokke \\ Department of Sociology and Human Geography, University of Oslo
}

\begin{abstract}
This is a theory-oriented article that discusses the meaning of politics of citizenship. The article argues that a broad conception of citizenship may provide an integral framework for studying political contentions over cultural, legal, social and political exclusion and inclusion. It starts out from an identification of four key dimensions of citizenship and defines politics of citizenship as contentious interactions over the institutionalisation and realization of substantive membership, legal status, rights and participation. This is followed by a review of cultural and global turns within the liberal nation-state model of citizenship, demonstrating that the form and substance of citizenship reflect contextual power relations and political contentions. Following from this observation, the article discusses the issues at stake in citizenship politics with special attention to three interrelated dimensions: politics of recognition for cultural inclusion, politics of redistribution for social justice, and politics of representation for political inclusion. This discussion points to fundamental tensions and strategic dilemmas, but also to points of convergence around affirmative and transformative remedies for injustice.
\end{abstract}

Keywords: citizenship, contentious politics, recognition, redistribution, representation 


\section{Introduction}

This is a theory-oriented article that discusses the meaning of politics of citizenship. I will argue that a broad conceptualization of citizenship may provide an integral framework for studying political contentions over cultural, legal, social and political exclusion and inclusion. While recent decades have seen increased scholarly attention to social movements, these have often been examined through single movement case studies with a tendency to see recognition, redistribution and representation as separate and even opposed claims (Fraser 2009; Isin \& Turner 2002; Tilly \& Tarrow 2007). I will argue that a broad notion of citizenship offers a conceptual basis for examining such struggles in a more integrative manner as politics of citizenship.

This agenda requires close attention to the meaning of citizenship. It can be observed that citizenship has gained increased political and scholarly interest, but also that the meaning of citizenship has been broadened and has become increasingly complex (Isin \& Turner 2002; Van der Heijden 2014). Vanderberg (2000) thus describes citizenship as an 'essentially contested concept' in the sense that it contains a variety of disputed meanings, with no agreed upon ways of settling these disagreements. The conventional understanding holds that citizenship is a legal status granted by a nation-state, i.e. what is commonly known as statsborgerskap in Scandinavian languages (Brochmann 2002). Social science studies on citizenship have, in contrast, increasingly focused on questions of cultural, social and political citizenship, i.e. what is captured by the Scandinavian term medborgerskap. The notion of citizenship is also used in an even more comprehensive manner to refer to both legal citizenship as well as cultural, social and political citizenship, i.e. what Brochmann (2002) describes as samfunnsborgerskap. 
Responding to this contested nature of the concept of citizenship, the first section identifies four key dimensions of citizenship - membership, legal status, rights and participation - and provides a brief outline of the core meaning of each. These dimensions come together in general models of citizenship, which is most clearly demonstrated by the hegemonic liberal nation-state model of citizenship (Schuck 2008). But it can also be observed that this model has undergone structural changes. The second section thus highlights a twofold shift in citizenship and citizenship studies: a cultural turn that has brought increased attention to cultural differences and group-differentiated rights within the liberal citizenship model; and a global turn that has problematised the spatiality of the nation-state model and envisioned postnational, denationalised and transnational forms of citizenship.

These transformations demonstrate that citizenship is never a fixed model, but is always contextual and political: The form and substance of citizenship are outcomes of competing interests, strategies and capacities within diverse political spaces. Membership, legal status, rights and participation are general stakes in politics of citizenship, while their institutionalised forms are also political spaces with strategic selectivity towards different agendas, actors and strategies (Jessop 2008).

The third section therefore discusses the meaning of politics of citizenship with special attention to three of these dimensions of citizenship: politics of recognition (the membership dimension of citizenship), politics of redistribution (citizenship as social rights) and politics of representation (citizenship as political participation). All three can be understood as struggles for realisation of substantive citizenship. This means that citizenship is 'a prism through which to address the political' (Nyers 2008, 3). The focus here is on the issues that are at stake rather than the actors and their strategies and political spaces. There is a very rich literature on 
contextual contentious politics in democratic, semi-democratic and non-democratic political systems, but the article does discuss the actors and dynamics of contention, due to space constraints (see Author \& Author 2013).

\section{Dimensions of Citizenship}

Although citizenship can be seen as an essentially contested concept and various authors provide different classifications of its core components, I will argue that there is a certain convergence around the key elements. The common understanding is that citizenship is about membership in a community that is the basis for formal status as citizen with rights and active citizenship associated with that status (Delanty 2000;

Faulks 2000; Joppke 2008). I will thus propose that modern citizenship can be understood as four interconnected dimensions: membership; legal status; rights and participation (Figure 1). Whereas membership and legal status are about cultural and juridical inclusion in communities of citizens, rights and participation are about the entitlements and responsibilities that follow from such inclusion.

$<$ Figure 1 near here>

All four dimensions are core components of citizenship, but their relative weight varies between different approaches. This is most clearly demonstrated by the emphasis on individual rights within the liberal approach, the focus on political participation in the civic-republican approach, and the primacy of communal belonging and participation in the communitarian approach to citizenship (Dagger 2002; Delanty 2002; Shuck 2002). The four-dimensional scheme proposed here is an 
attempt to sketch an open-ended integral framework for studying politics of citizenship without being wedded to any of these particular perspectives.

The following paragraphs provide brief descriptions of each dimension as a basis for discussing contemporary transformations of citizenship and the politics of citizenship in subsequent sections. The order of this presentation follows what may be seen as a conventional logic, from membership through legal status and rights to participation. This is a pragmatic matter of convenience and does not reflect or promote any evolutionary view on citizenship. On the contrary, I will argue that the four dimensions are mutually constitutive and represent different entry points and potential priorities in citizenship politics, rather than a fixed sequence or chain of causality.

\section{Citizenship as Membership}

The membership dimension highlights that citizenship is based on a distinction between insiders and outsiders in a community, but the meaning of community and the criteria for inclusion vary over time and space. While the original Greek model of citizenship was based on membership and participation for elites at the city scale, the Roman model granted legal rights without political participation to conquered populations to maintain control throughout the imperial territory (Magnette 2005). The modern meaning of citizenship rests on membership within a nation that is assumed to be bounded, homogenous and stable (Beckman \& Erman 2012; Brubaker 1992). This leads Heater (1999) to the observation that citizenship and nationality have been merged during the past two centuries.

This merging of citizenship and nationhood means that the nation has become a universal basis for defining the political community of citizens, but the national 
community may be constructed in different ways. A basic distinction is often made between ethno-cultural and juridical-political constructions of nationhood, that is; national communities built around either a cultural essence or a territorial state formation. France and Germany have often been used as ideal typical examples of these two models. Whereas French nationhood revolves around people living under common law and the same legislative assembly within the territorial state, German nationhood has been based on a notion of ethnic community with strong ties to a historical homeland (Brubaker 1992).

The nation-state model of citizenship accommodates such contextual variations in the construction of nationhood. It is, however, challenged more fundamentally by cultural diversity and identity politics within presumably homogenous nations. Citizenship and citizenship studies have thus seen an increased importance of denationalised, transnational and post-national constructions of membership (see below).

\section{Citizenship as Legal Status}

Based on membership in a national community, states ascribe citizenship as a legal status, which means that there is a contractual relation between an individual and the state that carries with it both rights and responsibilities. Heater (1999) notes that international law recognises the right of sovereign states to define who may be permitted to become citizens. Stemming from the distinction between ethno-cultural and juridical-political constructions of national communities, citizenship is acquired on the basis of the citizenship of parents (jus sanguinis) or on the basis of being born within the territory of a state (jus soli). In addition to these core principles, citizenship 
can under certain circumstances also be acquired by marrying a citizen (jus matrimonii) or through residence for a given time period (jus domicili).

While these ideal typical principles may appear simple, the practical reality of citizenship acquisition is not. Most real world citizenship models are complex combinations that 'lay somewhere in between the poles of territory and blood' (Samers 2010, 245). Such hybrid systems for legal citizenship have become more prominent in the context of increased international migration. This actualises naturalisation on the basis of length of residence and acceptance of dual citizenship. But the counter-argument can also be made that the current period of international migration is actually characterised by the re-assertion of ethnic notions of nationhood. Shachar (2009) thus describes citizenship as a birthright lottery in the sense that citizenship is a property that is transferred intergenerationally at birth (based on blood or place of birth), and creates a separation between winners who are born into wealth, rights and participatory opportunities, and those who are excluded from the citizenry of wealthy states. This leads to a proposal for an alternative principle for citizenship, jus nexi, where acquisition of citizenship is based on a genuine connection to a country, or in other words, the social fact of membership.

This proposal for jus nexi is especially relevant for people who are in situations between non-citizens and full citizens, for example noncitizen residents whose initial entry breached the law of the admitting state. Heater (1999) more generally observes that there are hierarchies of citizenship, stratified according to the rights and possibilities for political participation that are granted to different groups of citizens and residents. This notion of stratified citizenship adds more layers to the already complex principles and laws for formal citizenship. The prevalence of hybrid and stratified citizenship also blurs the idealised image of a binary distinction between 
citizens and non-citizens and of equality among citizens. Complexity in the principles for becoming a citizen is thus mirrored in diverse and stratified experiences of being a citizen (Castles \& Davidson 2000).

\section{Citizenship as Rights}

The third component of citizenship is the set of rights that are associated with membership and formal citizenship status. Individual civil liberties are the defining feature of citizenship according to the liberal approach, but rights also come in other forms (Roche 2002; Schuck 2002). The common categorisation that was pioneered by Marshall (1992) revolves around a threefold typology of civil, political and social rights. Civil rights are rights that protect individual security and privacy; rights to access to justice and legal representation; rights to enter contract and ownership of private property; and, rights to freedom of conscience and choice, including free speech and press, freedom of religion etc. Political rights are rights to participate in the public arena and political process, including rights to vote and stand for office, form political organisations and parties, express opposition and protest etc. Social rights include enabling welfare rights such as health care and pensions; opportunity rights especially in education and the labour market; redistributive and compensation rights such as low income, unemployment and work injury compensation (Janoski \& Gran 2002).

This catalogue of rights is not fixed but can be both broadened and deepened. Recent years have for example brought attention to environmental citizenship, that is, questions about rights to environmental qualities and protection against degradation, and questions about nature as a rights-bearing subject (M.J. Smith \& Pangsapa 2008). There are also critical questions about the mutuality and tensions between different 
kinds of rights, especially between individual civil and political freedoms based on principles of universality and equality, and social and cultural group rights that aim at addressing inequalities between social groups.

Another set of questions regard the dynamics and development of citizenship. Marshall (1992) has been criticised for presenting an evolutionary interpretation of the history of rights, and for portraying the historical development of citizenship in the UK as a universal model for expansion of rights. Some critics have pointed to examples of other sequences of rights and that social rights have at times emerged before rather than after political rights (Soysal 1994). Examples include welfare concessions under authoritarian rule (e.g. Germany in the late $19^{\text {th }}$ century) or the granting of limited social rights to immigrants despite their lack of citizenship status. The rolling back of welfare rights under neoliberal governance in recent years also challenges Marshall’s (1992) evolutionary view.

Critics have also charged Marshall (1992) for paying insufficient attention to the role of politics and struggles for citizenship. Turner (1986) for example argues that the modern history of citizenship should 'be conceived as a series of expanding circles which are pushed forward by the momentum of conflict and struggle' (Turner 1986, xii). Giddens (1987) similarly emphasizes class conflict as a driving force behind the expansion of citizenship (see also Barbalet 1988). Held (1989) supports this focus on political struggles and argues that 'the very meaning of particular rights cannot be adequately understood if the range of concerns and pressures which have given rise to them is not properly grasped' (D. Held 1989, 200). He is, however, critical of the tendency to limit the analysis of citizenship politics to class conflict, arguing that this mode of analysis fails to grasp the role and strategies of diverse groups, classes and movements. The key lesson from this debate on social rights is 
thus about the need for close attention to the politics of rights and the diversity of actors and agendas involved. This holds true for struggles over civil and political rights in the context of authoritarian rule, as well as struggles for social rights in the context of liberal democracy.

\section{Citizenship as Participation}

Citizenship also involves responsibilities, for example in the form of obligatory taxes or military service. Communitarian perspectives especially emphasise participation at the community level, and that active citizenship has an integrative function in the sense that it draws people out of the private sphere and into public life. To be a 'good citizen' is thus 'to be a self-governing member of a self-governing community' (Dagger 2002, 149). There is also a growing literature that broadens the meaning of community and participation, for example by focusing on environmental responsibilities and feminist ethics of care (Dobson \& Bell 2006; V. Held 2006; MacGregor 2014; M.J. Smith \& Pangsapa 2008). This emphasis on active citizenship means that the process of becoming a citizen is conceived not merely as a question of identity, legal status and rights (Joppke 2008), but also as a matter of active participation within communities of citizens.

Beyond community responsibilities, the foremost meaning of citizen participation is involvement in governance of public affairs (Van der Heijden 2014). Such political responsibilities are a prominent theme within the civic republican approach to citizenship (Dagger 2002). Citizenship thus has an intrinsic link to democratic politics and theory, with a long-standing distinction between direct participation and indirect representation as means for ensuring political control by citizens. Whereas the participatory model highlights people's direct involvement in 
decision-making and monitoring of public affairs, mediated representation is based on the notion of a democratic chain extending from rights-bearing citizens through elected representatives into democratic governance of public affairs (Pateman 1970; Saward 2010). The original exemplar of citizenship in Athens involved extensive participation, but was limited to elites who could devote time to the duties of citizenship (Magnette 2005; Pocock 1998). Such polity-wide assembly of citizens in deliberative democracy vanished with the rise of modern states, and political citizenship instead came to rely on some form of mediated representation. Thus liberal democracy within territorial states has become the hegemonic framing of political citizenship, but there is much contextual diversity in the form of citizens' involvement, and in the substance of popular political control (Harriss, Stokke \& Törnquist 2004; Törnquist, Webster \& Stokke 2009).

Recent decades have also brought renewed attention to direct democratic participation, especially at the local scale. On the one hand, participation in governance has become part of mainstream theory and practice in development interventions in the global South, but also within neo-liberal governance in general (Cooke \& Kothari 2001; Cornwall 2011; Gaventa \& McGee 2013; Hickey \& Mohan 2004). On the other hand, participation has also gained new attention through experiments in participatory local democracy, where the most prominent example is the institutionalisation of participatory budgeting at the city and municipal scales in Brazil (Abers 2000; Baiocchi 2005; Baiocchi, Heller \& Silva 2011; Fung \& Wright 2003). This participatory turn has yielded rich scholarship and debates at the intersection between citizenship, democracy, development and planning studies, paying special attention to the character of participatory spaces and the capacities and 
strategies of individuals and groups of citizens to use and transform such spaces (Van der Heijden 2014).

Examining the character of local political spaces, Cornwall (2004) makes a critical distinction between participatory spaces that are claimed by popular movements and spaces where targeted groups are invited to participate on terms that are defined from outside and above (see also Holston 2009). The notion of claimed spaces recognises the agency of citizens as makers and shapers rather than mere users and choosers, and hence portray participation as means for transformation and emancipation. This is in contrast to Chatterjee's (2004) analysis of how subject population in India are placed in a relationship to the state as subjects of governmentality. These are invited to participate on terms set by the state rather than being sovereign citizens that exert political control through democratic participation (Agarwala 2013; Millstein \& Jordhus-Lier 2012).

These brief comments imply that while participation has gained new prominence, the manner in which it is conceived and constructed have important implications for the substance of political citizenship. This supports the argument that citizens are stratified, not only in terms of their membership, legal status and rights, but also through differentiated possibilities and capacities for political participation. Janoski and Gran (2002) argue that such stratification is reflected in the citizens' selfconception and propose three ideal types of citizens on the basis on their political practices. First, participant citizens are either incorporated from above as supporters of the political elite or are active participants in mobilisation for political integration from below. Second, non-participant citizens may be deferential citizens that accept political authorities and programmes without providing active support, cynical citizens that are inactive and justify this with the impossibility of achieving political 
results, or marginal citizens that are alienated from the political system through exclusion or lack of required resources. Finally, opportunistic citizens prioritise their own interests and only participate politically if it directly affects their interests. All of this means that participation is a key dimension of citizenship, while also demonstrating the need to pay close analytical attention to complex and contextual interrelations between political spaces and the actor's political capacities and strategies.

\section{Mutuality between Membership, Legal Status, Rights and Participation}

Having provided brief accounts of four core dimensions of citizenship, I want to make the obvious point that these are inextricably interwoven. It has already been mentioned that membership is a basis for legal status, which in turn has a structuring effect on citizenship rights and participation. This seems to imply an element of sequencing, but I will argue that the interrelations between the four dimensions are more complex and multi-directional than this. Active citizenship, for example, has decisive influence on the discursive construction of cultural identity, and political participation is also central to the institutionalisation and realisation of different kinds of citizenship rights. Likewise, civil and political rights can be used as a basis for struggles over inclusive membership and legal status. Such formal status as a citizen also frames inclusion and belonging in communities of citizens. This means that the politics of citizenship should not be understood in a linear and sequential manner, but rather that the identified dimensions are interwoven entry points and stakes in openended political processes.

Finally, the four dimensions of citizenship and the substance of each allow us to think systematically about stratified forms of citizenship. Figure 1 indicates four 
kinds of partial citizenship depending on a person's status in regard to each of these dimensions. Stratified citizenship may also originate within each of the four dimensions, i.e. through differentiated membership, legal status, rights and participation. This understanding of citizenship as partial and stratified, despite the emphasis on universality and equality within the liberal model, has gained increased attention in recent decades in the context of globalization, international migration and changing forms of governance.

\section{Contemporary Transformations in Citizenship}

Castles and Davidson (2000) argue that citizenship has gone from being a matter of common sense to become problematic and contested. This shift is ascribed to general transformations in society, but also increased sensitivity to contradictions within the nation-state model of citizenship. Taylor (2010) more specifically observes that increased globalisation and multiculturalism have accentuated territorial and cultural tensions within the liberal model of citizenship, and thereby paved the way for 'global' and 'cultural' turns in citizenship studies.

\section{The Cultural Turn in Citizenship Studies}

The liberal model of citizenship rests on assumptions about cultural homogeneity in the sense that it is based on imagined national communities with proclaimed cultural sameness. The cultural turn in citizenship refers to growing academic and political questioning of this assumed universality and demands for group recognition and rights. The core of this cultural turn can be briefly summarised with reference to the 
influential writings of Young (1990) and Kymlicka (1995) and the debates surrounding these.

Young's $(1990 ; 1998)$ criticism of liberal citizenship rests on her analysis of universality. The universality of citizenship means that all members of a political community are granted citizenship on equal terms. It also means that commonality of identity is privileged at the expense of particularistic group belonging, and that all are treated equally in the sense that laws and rules apply to all in the same way. The liberal perspective holds that these three meanings of universality are mutually reinforcing and construct citizenship in a manner that transcends particularity and difference in favour of equality and justice. Young $(1990 ; 1998)$ argues, in contrast, that the emphasis on common identity conceals that citizenship is defined in terms of dominant identities and thus put other identity groups at a disadvantage, even though everyone is granted equal citizenship in legal terms. This means that while universal citizenship is an instrument of emancipation and justice, it simultaneously masks and accentuates group oppression in terms of gender, sexuality, class, ethnicity and so on (Lister 2002; 2008).

The core premise for Young's $(1990 ; 1998)$ work is that every society contains group differentiation and oppression that make group belonging real to its members. Young defines an oppressed group as one where all or a large portion of its members experience one or more of five key mechanisms of oppression: exploitation, marginalisation, powerlessness, cultural imperialism and violence. In this situation, citizenship is not merely an individual status but is also shaped by group identity and shared experiences of oppression. This means that full citizenship requires groupdifferentiated rights in addition to universal individual rights. It is only by recognising 
difference and providing institutional mechanisms for group representation that pluralist societies can move towards justice for all.

Kymlicka (1995) presents a related defence for group-differentiated rights, based within the liberal perspective on citizenship. His point of departure is that modern societies are increasingly multicultural, both due to territorial incorporation of previously autonomous cultures and because of increased international migration. The key question that arises in this situation is about the implications of multiculturalism for citizenship in terms of membership, legal status, rights and participation (Massoumi \& Meer 2014).

Kymlicka (1995) is especially concerned with the question of group rights and how it relates to the liberal conception of universal citizenship. He observes that there is a convergence between left and right liberals in the sense that both 'reject the idea of permanent differentiation in the rights or status of the members of a certain group' (Kymlicka 1995, 4, italics in original). The common view is that ethnic identity, like religion, should be separated from the state and relegated to the private sphere: The state should adopt a strategy of protection against discrimination and prejudice but otherwise refrain from interference. In contrast, Kymlicka (1995) argues that group inequality, historical group rights and cultural diversity call for three different kinds of group-differentiated rights: self-government rights (devolution of power to minorities within the state); polyethnic rights (protection and support for minority identity and practices); and special representation rights (guaranteed representation for minorities in political institutions).

This typology raises critical questions about the implication of group rights for identity and belonging in multi-cultural societies. While universal citizenship is normally seen as the primary tool of integration, group-differentiated rights are often 
portrayed as a mechanism for institutionalisation of difference. Self-government rights may thus function as a precursor to secession rather than political integration. Kymlicka (1995) argues that representation rights and polyethnic rights are consistent with integrating minorities, while self-government challenges the definition of the political community and the sovereignty of the state. Denying self-government rights can, however, also be a threat to unity and encourage secessionist struggles. Concerns about social unity are thus unavoidable and may arise in the context of multiculturalism as well as majoritarianism within the larger political community. Young (1990; 1998) and Kymlicka (1995) thus provide different justifications for the shared conclusion that citizenship must acknowledge the existence of group differences and hence institutionalise group-differentiated rights. Such analyses and recommendations have been much debated among both scholars and political actors. The main point of contention revolves around the tension between universality and group rights as indicated above. In addition to this comes a critique of how social groups are conceptualised. While both authors have been instrumental in bringing group belonging into citizenship studies, their conception of cultural groups remains essentialist in the sense that the demarcation of oppressed groups and national/ethnic minorities is not examined critically. Internal group differences and multiple and changing identities are downplayed, producing a static and deterministic understanding of collective and individual identity and interests (Joppke 2002).

Faulks thus observes that 'in seeking to transcend what Young sees as the essentialist individualism of liberal citizenship, she merely replaces it with an equally essentialist definition of the social group' (Faulks 2000, 91). This is at the core of debates between identity politics and politics of difference, as alternative approaches 
to cultural politics of citizenship, and will be further discussed below (Isin \& Wood 1999).

\section{The Global Turn in Citizenship Studies}

The liberal model of citizenship rests on assumptions about territorially bound states and nations (Author 2017). This nation-state model of citizenship has come under pressure as economic globalisation has challenged the sovereignty of the state and contributed to the emergence of multi-scale forms of governance and citizenship (Fraser 2009). Furthermore, neo-liberal governance means that membership, rights and participation are not only defined by the citizens' relations to the state, but also by the market and even civil society. Finally, increased international mobility has produced a growing number of people with dual citizenship or transnational belonging. While the state remains a pivot for citizenship, these processes mean that citizenship has come to be defined with reference to diverse domains of governance and multiple scales and territories (Figure 2). Citizenship has thus become increasingly complex in geographic terms (Desforges, Jones \& Woods 2005; Ong 2006).

$<$ Figure 2 near here $>$

Sassen (2002) observes that the decentring of citizenship means that we are seeing the emergence of denationalised, transnational and post-national citizenship. Denationalisation and transnationalisation refer to geographic transformations, where citizenship nevertheless remains within the logic of the nation-state model. The postnational trajectory, in contrast, means that citizenship comes to be located outside the 
nation-state framework in the sense that it constructs new forms of community and transcends the state institutional framework.

Denationalisation refers to a transformation of citizenship away from the national scale, which is especially visible in the emergence of multi-level citizenship. The most obvious example of denationalisation can thus be found in federal states, where individual citizens hold rights and responsibilities at the level of both the federation and the sub-states (Heater 1999). Devolution of power to semi-autonomous regions in a quasi-federal state or to municipalities and cities within a decentralised state structure provide additional examples of multi-level citizenship (Ong 2008). At the other scalar end, there are also examples of citizenship at the supranational level based on the nation-state model, for example citizenship status, rights and political participation at the scale of the European Union (Bellamy 2000; Delanty 2008; Painter 2002).

Transnational citizenship means that citizenship remains within the ordering logic of the nation-state model. However, international migration creates a situation where formal citizenship may be with reference to more than one territorial state, and where belonging and active citizenship are with reference to multiple political and social spaces in countries of origin and immigration, as well as in transnational fields of diasporas (Al-Ali \& Koser 2002; Brubaker 2010; Erdal 2012; Faist 2000; Levitt \& Glick Schiller 2004; Tharmalingam 2011; Vertovec 2009).

Post-national citizenship is a more radical departure from the nation-state model since it involves constructions of communities of citizens outside the framework of the nation. A pioneer study is presented by Soysal (1994), who argues that, there has been a shift to post-national citizenship centred on universal personhood and human rights rather than nationhood. This means that the boundaries 
of membership are fluid, and that the legitimising framework has shifted from the national to the global scale and from state-centric rights to human rights. This does not mean, however, that the state has become irrelevant, since the realisation of international human rights conventions is still tied to states. A foremost example of post-national citizenship is found in discourses on cosmopolitan citizenship where 'cosmopolitan community is replacing national community’ (Delanty 2000, 2). Global identities, risks and responsibilities for developing effective institutions to handle challenges such as global poverty, inequality, human rights and environmental change, are important nodal points for constructing cosmopolitan communities and active citizenship (Benhabib 2008; Cabrera 2010; Linklater 2002; O'Byrne 2003; R.M. Smith 2002; Tijsterman 2014).

The notion of post-national citizenship and Soysal's (1994) work have gained acclaim and received strong criticism. Critical questions have especially been asked about the substance of rights for non-citizen residents (Bhabha 1998; Kofman 2006). There has also been much debate about the extent of post-national political participation in the absence of robust democratic institutions at the global scale (Falk 1994; D. Held 2010; Linklater 2002; R.M. Smith 2002). Nevertheless, post-national citizenship draws attention to constructions of community and new forms of citizenship outside the framework of the nation-state model, including global citizenship as well as occupational citizenship (Standing 2009), environmental citizenship (Dobson \& Bell 2006) and sexual citizenship (Bell \& Binnie 2000).

The cultural and global turns, in the context of increasingly globalised and multicultural societies, have thus challenged the hegemony of a fixed nation-state model of citizenship. Citizenship and rights are thus 'continually developing and 
should not be regarded at any historical moment as having attained a final, definitive form' (Bottomore 1992, 91).

\section{Politics of Citizenship}

The above discussion highlights that citizenship is always a matter of politics in the sense that the form and substance of membership, status, rights and participation are contextual outcomes of political contentions (Clarke, Coll, Dagnino \& Neveu 2014; Van der Heijden 2014). Following from the previous section, I will define politics of citizenship as struggles for institutionalised and substantive membership, legal status, rights and participation, or in other words, cultural, judicial, social and political justice. Such citizenship politics is inherently complex in terms of actors, interests, strategies and capacities. It is equally multifaceted in geographic terms, as citizenship is politicised and institutionalised within diverse territories and places, at multiple and interrelated scales, and through spatial networks across places, territories and scales. The following paragraphs will present a brief and general discussion of the principal issues that are being politicised. It will pay less attention to the actors and their strategies and capacities, due to space constraints (Van der Heijden 2014). I will argue that these principal issues can be understood as interrelated and at times opposed claims for cultural, judicial, social and political justice. Fraser's (1995; 2009; Fraser \& Olson 2008) conception of justice will be used as a heuristic analytical framework, emphasising especially the three dimensions of citizenship that can be grouped together under the Scandinavian term 'medborgerskap': politics of recognition the membership dimension of citizenship), politics of redistribution (citizenship as social rights) and politics of representation (political citizenship). 


\section{Different Forms of Injustice and Struggles for Justice}

The point of departure for Fraser's analyses is a differentiated analysis of injustice, and especially an analytical distinction between economic and cultural forms of injustice that give rise to different social groups and struggles for justice (Fraser 1995; Fraser \& Olson 2008) (Table 1). Economic injustices, on the one hand, are rooted in political-economic structures and involve exploitation, marginalisation and deprivation along class divisions. This forms the basis for politics of redistribution and strategies to reallocate resources or eliminate economic barriers, thereby reducing socio-economic inequalities. Cultural injustices, on the other hand, are rooted in patterns of symbolic representation manifested as cultural domination, nonrecognition and disrespect. Such cultural injustices yield politics of recognition with calls for affirmative action or transformation of the categorical identities that are at the core of misrecognition. Fraser's more recent work has drawn additional attention to political misrepresentation as a third form of injustice, producing politics of representation, including at scales above the nation-state (Fraser 2005; 2009).

Next, Fraser (1995) identifies three idealtypical collectivities based on the analytical distinction between economic and cultural injustices. While social classes are rooted in the political economy of maldistribution and tend to prioritise politics of redistribution, collectivities based on cultural misrecognition (for example devalued sexualities) typically emphasise politics of recognition. Between these two idealtypes, there are hybrid collectivities that combine traits of exploited classes with features of misrecognised identity groups.

\footnotetext{
$<$ Table 1 near here>
} 
Fraser (1995) argues that gender and race are prime examples of such bivalent collectivities that may pursue for both redistribution and recognition. This situation is dilemmatic because it raises questions about strategic priorities between cultural and economic forms of injustice and struggles for justice. It can for example be noted that politics of citizenship during the Cold War had a primary focus on socio-economic rights in the context of first-world social democracy, second-world communism and third-world developmentalism. Recent decades have, in contrast, brought increased attention to questions of cultural inclusion, most clearly demonstrated by identity politics championed by various social movements (C. Taylor 1994; Nicholson 2008). It can thus be argued that there has been a general shift in popular struggles for justice from a primacy of redistribution to an increased emphasis on recognition. This has created polarised scholarly and political debates about the relative importance of different forms of injustice and the strategic priorities in collective struggles, especially demonstrated by different waves of feminism (Fraser 2005).

\section{Identity Politics and Politics of Difference}

The strategic choice between redistribution and recognition has important implications for the future of the collectivities. To put it simply, politics of redistribution seek to remove inequality and hence erode class categories, whereas politics of recognition aims at cultural valorisation and thus reinforce identity groups. The key question is thus whether justice should be pursued in a manner that enhance or de-differentiate collectivities. This is especially visible in a divide between identity politics and politics of difference within cultural politics of citizenship (Isin \& Wood 1999). Identity politics, on the one hand, is based on shared experiences of injustice 
stemming from involuntary membership in a particular social group, yielding demands for inclusion through affirmative action (group rights) within the liberal model of citizenship (Young 1990). Politics of difference, on the other hand, foreground the constructed character of groups and the need to deconstruct categorical identities in order to achieve equal and substantive citizenship (Lister 2008). Identity politics, it is argued, fail to capture the complexity of identification and freezes categorical identities, thereby limiting individual autonomy and replacing 'one kind of tyranny with another' (Appiah 1994, 163). Proponents of identity politics criticise the politics of difference for only being capable of theoretical deconstruction, not any political mobilisation that matters (Hartsock 1998).

Cultural politics of citizenship have thus come to be characterised by strategy discussions that are intertwined with scholarly debates around essentialist and constructivist perspectives on identity. Isin and Wood (1999) argue that both are incomplete and that there is a need to transcend this divide. The well-known shortcoming of essentialism is that it is impossible to classify the diversity of social positions and identities in objective and discrete terms (Brubaker 2004). Laclau and Mouffe (1985) famously argue that there cannot be any unitary subject, only an ensemble of discursively constructed subject positions that provide spaces for subjective identification. This means that identity is 'always contingent and precarious, temporarily fixed at the intersection of those subject positions and dependent on specific forms of identification' (Mouffe 1995, 33). It also means that subject formation is a prime political site: 'politics is not about defending the intrinsic interests of a political subject but about a struggle to construct subjects, making identity a primary ground for the operation of politics' (Rasmussen \& Brown 2002, 182). This understanding of identity as discursively constructed subject positions is, 
however, challenged by the strong sense of group attachment that is demonstrated by identity politics. The core challenge for constructivism is thus to explain that socially constructed identities appear so real and emotionally charged.

Isin and Wood (1999) thus call for critical attention to the articulation between symbolic constructions of categorical identities and individual attachment to collectivities, and propose that Bourdieu's theory of social practice may provide analytical tools for addressing this challenge (Bourdieu 1977; 1990). The foremost connecting link is the notion of habitus, which refers to inculcated dispositions that make actors inclined to understand the world and act in certain ways. Habitus is a structuring structure in the sense that it yields habitual practices, but is itself a structured structure since the embodied dispositions are rooted in social differentiation. This social conditioning means that habitus is to a certain extent collective, because individuals may share similar locations in social space and similar experiences in specific fields of practice. It is thus possible to identify collectivities, even though these must be understood as theoretical categories rather than objectively given and discrete groups (Bourdieu 1987).

Bourdieu (1991) combines this sociology of theoretical categories with analytical attention to group-making through symbolic representation (Author \& Author 2009; Saward 2010). The defining practice of political representation, he argues, is to constitute the social world by symbolic means (Bourdieu 1991). Political actors are involved in symbolic struggles to impose and normalise representations of the world that suit their own interest. To be successful in producing and mobilising a group of people, representations must resonate with the habitus of those they intend to mobilise (Crossley 2002). Thus, the making of identities and movements is not about a realisation or awakening of a group that is predefined by objective criteria, but 
rather about symbolic constructions that articulate with the habitus of individuals who share similar positions in social space (Brubaker 2004). This provides a strategy for understanding group formation and attachment, yet foregrounding that they are constructions that are open for transformation and deconstruction. It also highlights that categorical identities are both tools and targets for citizenship politics. Building an effective movement against group injustice requires constructions of collectivities, yet the success of popular politics of citizenship may be measured by the ability to eradicate social differentiations and group constructions.

\section{Affirmative and Transformative Remedies for Injustice}

Fraser's (1995) answer to these strategic dilemmas is to observe that the two principal remedies for injustice - affirmation and transformation - cut across the divide between redistribution and recognition (Table 1). In simplified terms, affirmation refers to remedies that seek to remove inequalities without changing its underlying structures, whereas transformation implies fundamental changes in the structures of injustice. Affirmative redistribution, which is typically associated with the liberal welfare state, seeks to redress inequitable outcomes without changing politicaleconomic structures. Transformative strategies, for example those associated with socialism or social democracy, seek instead to change structural power relations in order to address unequal distributional outcomes. Likewise, affirmative recognition strategies exemplified by homosexual identity politics aim to revalue gay and lesbian identity, while transformative remedies seek to deconstruct the homo-hetero dichotomy as argued within queer theory.

These two distinctions, between redistribution and recognition and between affirmation and transformation, create different possibilities for integrated remedies 
for injustice. Fraser (1995) argues that the diagonal combinations in Table 1 (affirmative redistribution combined with transformative recognition, and transformative redistribution combined with affirmative recognition) are contradictory because they simultaneously seek to promote and deconstruct groups. The vertical combinations (affirmative redistribution and recognition, and transformative redistribution and recognition), in contrast, avoid this built-in tension. These hold a potential for integrated transformative politics, for example to redress gender injustice:

Transformative redistribution to redress gender injustice in the economy consists in some form of socialist feminism or feminist social democracy. And transformative recognition to redress gender injustice in the culture consists in feminist deconstruction aimed at dismantling androcentrism by destabilizing gender dichotomies. Thus the scenario in question combines the socioeconomic politics of socialist feminism with the cultural politics of deconstructive feminism. (Fraser 1995, 89)

This analysis supports the conclusion that the dilemma is not merely about prioritising recognition or redistribution, but whether it should be pursued through affirmative or transformative remedies.

\section{Politics of Representation}

The previous sections have pointed to the political nature of citizenship with special attention to the relations between politics of redistribution and politics of recognition. This section discusses politics of representation as a third dimension of injustice and citizenship politics. These three idealtypes - politics of recognition, redistribution and 
representation - correspond to the membership, rights and participation dimensions of citizenship that were identified at the beginning of the article.

It has already been discussed how people can be prevented from equal citizenship due to lack of material resources or denial of cultural status, giving rise to politics of redistribution and recognition. The same logic also applies to politics. The political field is a key site for struggles for redistribution and recognition, as well as a separate domain of injustice. Fraser (2009) has thus come to advocate a threedimensional conceptualisation of justice, adding misrepresentation as the principal form of political injustice and politics of representation as a third mode of struggle for justice.

The political dimension of justice is first and foremost centred on political framing and procedures. Whereas the former refers to political boundary-setting, i.e. who is included in the demos and allowed a political say and what is defined as public affairs, the latter refers to the organisation of contestation and decision-making. Consequently, political injustice can originate at two principal levels: by political misframing whereby groups are excluded from participation and key issues are left out from public affairs, and by flawed political representation that fails to establish effective mechanisms for popular control over public affairs (Törnquist et al. 2009). It follows from this discussion that misrepresentation revolves around three principal components of representation: (1) the constitution of public affairs; (2) the construction of demos; and (3) the links between people and governance of public affairs (Beetham 1999; Törnquist 2009). Such problems of political procedures have gained much attention, not the least in the contemporary context of minimalist democracies characterised by flawed procedures of popular representation, and by 
neo-liberal governance whereby public affairs are handled in a technocratic manner with limited and top-down forms of participation (Harriss et al. 2004).

Fraser (2009) argues that misframing is a fundamental behind such flawed political procedures for representation. This is clearly demonstrated by the scalar mismatch between global processes that shape the character of injustice in the contemporary era, and the continued prevalence of territorial states as the foremost domain for popular political representation. In this situation, people find that they are denied the chance of effectively addressing injustice because of the transnational character of the structures that perpetuate injustice. These forces, Fraser (2009) argues, belong to the transnational spaces of flows rather than the territorial spaces of places. Being 'not locatable within the jurisdiction of any actual or conceivable territorial state, they cannot be made answerable to claims of justice that are framed in terms of state-territorial principle' (Fraser 2009, 23). This problem of misframing is brought out clearly in contemporary debates about scalar strategies of labour organising in the context of global economic transformations, but also in scalar relations that frame the spaces and strategies for localised popular struggles for justice (Jordhus-Lier 2013; Lier \& Stokke 2006; Millstein, Oldfield \& Stokke, 2003; Oldfield $\&$ Stokke 2006).

If political misrepresentation is accepted as a third form of injustice, what is the core meaning of politics of representation? Mirroring the earlier discussion, a distinction can be made between affirmative and transformative strategies for improved representation (Table 1). At the level of political procedures, affirmative strategies may be exemplified by demands for quotas or proportional representation within electoral systems of liberal democracy. Transformative politics of representation, in contrast, start out from the democratic aim of popular control over 
public affairs and seek to transform the delimitation of people and public affairs as well as create substantive democratic links between people and governance (Author $\&$ Author 2013; Törnquist et al. 2009). In the case of scalar misframing, affirmative politics seek to rescale the frame while remaining within the Westphalian logic of governance, for example by demanding state-like structures above the nation-state. Transformative strategies, in contrast, searches for post-territorial forms of popular control over public affairs, for example by insisting that all people that are affected by a transnational structure of injustice should have an equal say in its governance.

\section{Conclusion}

This article has been motivated by the common concern that movement politics and studies have been marked by tendencies towards fragmentation and lack of an overarching framework (Author \& Author 2013). In response, the article has put forth the proposal that a broad conception of citizenship may provide an integral analytical framework for scholarship on movement politics for cultural, juridical, social and political inclusion. The aim has thus been to explore the meaning of politics of citizenship, focusing on the issues that are at stake rather than the actors, strategies and contentious interactions that are involved in citizenship politics. As citizenship is itself a contested concept, I have proposed a conception that revolves around four closely interrelated core dimensions: membership, legal status, rights and participation. The article has also argued that although these dimensions come together in seemingly fixed citizenship models, substantive variations and transformations demonstrate that the form and substance of citizenship reflect contextual power relations and political contentions. Following from this observation, the article has proposed a working definition of citizenship politics as contentious 
interactions over the institutionalisation and realization of substantive membership, legal status, rights and participation. My brief discussion of recent debates on the politics of recognition, redistribution and representation points to fundamental tensions and strategic dilemmas, but also to points of convergence around crosscutting affirmative and transformative remedies for injustice. The continued scholarly and political challenge is to examine and promote transformative democratic politics as means for realisation of substantive citizenship within and across its constitutive dimensions (Author \& Author 2013).

\section{References}

Author 2017. Reference removed for peer-review.

Author \& Author 2009. Reference removed for peer-review.

Author \& Author 2013. Reference removed for peer-review.

Abers, R.N. 2000. Inventing Local Democracy: Grassroots Politics in Brazil. Boulder: Lynne Rienner.

Agarwala, R. 2013. Informal Labor, Formal Politics, and Dignified Discontent in India. Cambridge: Cambridge University Press.

Al-Ali, N., \& Koser, K. (eds.) 2002. New Approaches to Migration? Transnational Communities and the Transformation of Home. London: Routledge.

Appiah, K.A. 1994. Identity, authenticity, survival: Multicultural societies and social reproduction. Taylor, C. (ed.) Multiculturalism: Examining the Politics of Recognition, 149-164. Princeton: Princeton University Press.

Baiocchi, G. 2005. Militants and Citizens: The Politics of Participatory Democracy in Porto Alegre. Stanford: Stanford University Press. 
Baiocchi, G., Heller, P., \& Silva, M.K. 2011. Bootstrapping Democracy: Transforming Local Governance and Civil Society in Brazil. Stanford: Stanford University Press.

Barbalet, J.M. 1988. Citizenship. Milton Keynes: Open University Press.

Beckman, L., \& Erman, E. (eds.) 2012. Territories of Citizenship. Basingstoke: Palgrave Macmillan.

Beetham, D. 1999. Democracy and Human Rights. Oxford: Polity Press.

Bell, D., \& Binnie, J. 2000. The Sexual Citizen: Queer Politics and Beyond. Cambridge: Polity Press.

Bellamy, R. 2000. Citizenship beyond the nation state: The case of Europe. O'Sullivan, N. (ed.) Political Theory in Transition, 91-112. London: Routledge.

Benhabib, S. 2008. Twilight of sovereignty or the emergence of cosmopolitan norms. Isin, E.F., Nyers, P. \& Turner, B.S. (eds.) Citizenship between Past and Future, 18-35. London: Routledge.

Bhabha, J. 1998. "Get Back to where you once belonged": Identity, citizenship, and exclusion in Europe. Human Rights Quarterly 20, 592-627.

Bohman, J. 2014. Republican citizenship. Van der Heijden, H.-A. (ed.) Handbook of Political Citizenship and Social Movements, 45-59. Cheltenham: Edward Elgar.

Bottomore, T. 1992. Citizenship and social class, forty years on. Marshall, T.H. \& Bottomore, T. (eds.) Citizenship and Social Class, 55-93. London: Pluto. Bourdieu, P. 1977. Outline of a Theory of Practice. Cambridge, UK: Cambridge University Press. 
Bourdieu, P. 1987. What makes a social class? On the Theoretical and Practical Existence of Groups. Berkeley Journal of Sociology 32, 1-18.

Bourdieu, P. 1990. The Logic of Practice. Stanford: Stanford University Press.

Bourdieu, P. 1991. Language and Symbolic Power. Cambridge: Polity.

Brochmann, G. 2002. Statsborgerskap, medborgerskap og tilhørighet. Brochmann, G., Borchgrevink, T. \& Rogstad, J. (eds.) Sand i maskineriet: Makt og demokrati $i$ det flerkulturelle Norge, 56-84. Oslo: Gyldendal Akademisk.

Brubaker, R. 1992. Citizenship and Nationhood in France and Germany. Cambridge: Harvard University Press.

Brubaker, R. 2004. Ethnicity without Groups. Cambridge: Harvard University Press.

Brubaker, R. 2010. Migration, membership, and the modern nation-state: Internal and external dimensions of the politics of belonging. Journal of Interdisciplinary History 41(1), 61-78.

Cabrera, L. 2010. The Practice of Global Citizenship Cambridge: Cambridge University Press.

Castles, S., \& Davidson, A. 2000. Citizenship and Migration: Globalization and the Politics of Belonging. Basingstoke: Macmillan.

Chatterjee, P. 2004. The Politics of the Governed: Reflections on Popular Politics in Most of the World. New York: Columbia University Press.

Clarke, J., Coll, K., Dagnino, E., \& Neveu, C. 2014. Disputing Citizenship. Bristol: Policy Press.

Cooke, B., \& Kothari, U. (eds.) 2001. Participation: The New Tyranny? London: Zed.

Cornwall, A. 2004. Spaces for transformation? Reflections on issues of power and difference in development. Hickey, S. \& Mohan, G. (eds.) Participation from 
Tyranny to Transformation? Exploring New Approaches to Participation in Development, 75-91. London: Zed.

Cornwall, A. (ed.) 2011. The Participation Reader. London: Zed.

Crossley, N. 2002. Making Sense of Social Movements. Buckingham: Open University Press.

Dagger, R. 2002. Republican citizenship. Isin, E.F. \& Turner, B.S. (eds.) Handbook of Citizenship Studies, 145-157. London: Sage.

Delanty, G. 2000. Citizenship in a Global Age: Society, Culture, Politics. Buckingham: Open University Press.

Delanty, G. 2008. European citizenship: A Critical Assessment. Isin, E.F., Nyers, P. \& Turner, B.S. (eds.) Citizenship between Past and Future, 61-70. London: Routledge.

Desforges, L., Jones, R., \& Woods, M. 2005. New geographies of citizenship. Citizenship Studies 9(5), 439-451.

Dobson, A., \& Bell, D. (eds.) 2006. Environmental Citizenship. Cambridge: MIT Press.

Erdal, M. B. 2012. Transnational Ties and Belonging: Remittances from Pakistani Migrants in Norway. (PhD), University of Oslo.

Faist, T. 2000. Transnationalization in international migration: Implications for the study of citizenship and culture. Ethnic and Racial Studies, 23(2), 189-222.

Falk, R. 1994. The making of global citizenship. Van Steenbergen, B. (ed.) The Condition of Citizenship, 127-140. London: Sage.

Faulks, K. 2000. Citizenship. London: Routledge.

Fraser, N. 1995. From redistribution to recognition? Dilemmas of justice in a 'postsocialist' age. New Left Review 212, 68-93. 
Fraser, N. 2005. Mapping the feminist imagination: From redistribution to recognition to representation. Constellations 12(3), 295-307.

Fraser, N. 2009. Scales of Justice. Reimagining Political Space in a Globalizing World. New York: Columbia University Press.

Fraser, N., \& Olson, K. (eds.) 2008. Adding Insult to Injury. Nancy Fraser Debates her Critics. London: Verso.

Fung, A., \& Wright, E.O. (eds.) 2003. Deepening Democracy: Institutional Innovations in Empowered Participatory Governance. London: Verso.

Gaventa, J., \& McGee, R. (eds.) 2013. Citizen Action and National Policy Reform. London: Zed.

Giddens, A. 1987. Social Theory and Modern Sociology. Oxford: Polity Press.

Harriss, J., Stokke, K., \& Törnquist, O. (eds.) 2004. Politicising Democrazy: The New Local Politics of Democratisation. Basingstoke: Palgrave.

Hartsock, N.C.M. 1998. The Feminist Standpoint Revisited \& Other Essays. Boulder: Westview.

Heater, D. 1999. What is Citizenship? Cambridge: Polity.

Held, D. 1989. Political Theory and the Modern State. Stanford: Stanford University Press.

Held, D. 2010. Cosmopolitanism: Ideals, Realities and Deficits. Cambridge: Polity.

Held, V. 2006. The Ethics of Care: Personal, Political, and Global. Oxford: Oxford University Press.

Hickey, S., \& Mohan, G. 2004. Participation from Tyranny to Transformation? Exploring New Approaches to Participation in Development. London: Zed.

Holston, J. 2009. Insurgent Citizenship: Disjunctions of Democracy and Modernity in Brazil. Princeton: Princeton University Press. 
Isin, E.F., \& Turner, B.S. (eds.) 2002. Handbook of Citizenship Studies. London: Sage.

Isin, E.F., \& Wood, P.K. 1999. Citizenship \& Identity. London: Sage.

Jessop, B. 2008. State Power. Cambridge: Polity.

Janoski, T., \& Gran, B. 2002. Political citizenship: Foundations of rights. Isin, E.F. \& Turner, B.S. (eds.) Handbook of Citizenship Studies, 13-52. London: Sage.

Joppke, C. 2002. Multicultural citizenship. Isin, E.F. \& Turner, B.S. (eds.) Handbook of Citizenship Studies, 245-258. London: Sage.

Joppke, C. 2008. Transformation of citizenship: Status, rights, identity. Isin, E.F., Nyers, P. \& Turner, B.S. (eds.) Citizenship between Past and Future, 36-47. London: Routledge.

Jordhus-Lier, D. C. 2013. Trade unions and democratic transformative politics: Political representation and popular mobilization during local government reform in South Africa. Stokke, K. \& Törnquist, O. (eds.) Democratization in the Global South: The Importance of Transformative Politics, 195-216. Basingstoke: Palgrave-Macmillan.

Kofman, E. 2006. Citizenship, migration and the reassertion of national identity. Citizenship Studies 9(5), 453-467.

Kymlicka, W. 1995. Multicultural Citizenship. New York: Oxford University Press. Laclau, E., \& Mouffe, C. 1985. Hegemony and Socialist Strategy: Towards a Radical Democratic Politics. London: Verso.

Levitt, P., \& Glick Schiller, N. 2004. Conceptualizing simultaneity: A transnational social field perspective on society. International Migration Review 38(3), 1002-1039. 
Lier, D.C., \& Stokke, K. 2006. Maximum working class unity? Challenges to local social movement unionism in Cape Town. Antipode 38(4), 802-824.

Linklater, A. 2002. Cosmopolitan citizenship. Isin, E.F. \& Turner, B.S. (eds.) Handbook of Citizenship Studies, 317-332. London: Sage.

Lister, R. 2002. Sexual citizenship. Isin, E.F. \& Turner, B.S. (eds.) Handbook of Citizenship Studies, 191-207. London: Sage.

Lister, R. 2008. Inclusive citizenship: Realizing the potential. Isin, E.F., Nyers, P. \& Turner, B.S. (eds.) Citizenship between Past and Future, 48-60. London: Routledge.

MacGregor, S. 2014. Ecological citizenship. Van der Heijden, H.-A. (ed.) Handbook of Political Citizenship and Social Movements, 107-132. Cheltenham: Edward Elgar.

Magnette, P. 2005. Citizenship: The History of an Idea. Colchester: ECPR Press.

Marshall, T.H. 1992. Citizenship and Social Class. Marshall, T.H. \& T. Bottomore, T. (eds.) Citizenship and social class, 3-51. London: Pluto.

Massoumi, N., \& Meer, N. 2014. Multicultural citizenship. Van der Heijden, H.-A. (ed.) Handbook of Political Citizenship and Social Movements, 86-106. Cheltenham: Edward Elgar.

Millstein, M., \& Jordhus-Lier, D. 2012. Making communities work? Casual labour practices and local civil society dynamics in Delft, Cape Town. Journal of Southern African Studies 38(1), 183-201.

Millstein, M., Oldfield, S., \& Stokke, K. 2003. uTshani BuyaKhuluma - The grass speaks: The political space and capacity of the South African Homeless People's Federation. Geoforum 34(4), 457-468. 
Mouffe, C. 1995. Democratic politics and the question of identity. Rajchman, J. (ed.) The Identity in Question, 33-46. London: Routledge.

Nicholson, L. 2008. Identity before Identity Politics. Cambridge: Cambridge University Press.

Nyers, P. 2008. Introduction: Why citizenship studies. Isin, E.F., Nyers, P. \& Turner, B.S. (eds.) Citizenship between Past and Future, 1-4. London: Routledge.

O'Byrne, D. 2003. The Dimensions of Global Citizenship. London: Routledge.

Oldfield, S., \& Stokke, K. 2006. Building unity in diversity: Social movement activism in the Western Cape Anti-Eviction Campaign. Ballard, R., Habib, A. \& Valodia, I. (eds.) Voices of Protest: Social Movements in Post-Apartheid South Africa, 111-132. Durban: University of KwaZulu-Natal Press.

Ong, A. 2006. Mutations in citizenship. Theory, Culture \& Society 23(2-3), 499-531.

Ong, A. 2008. Please stay: Pied-a-Terre subjects in the megacity. Isin, E.F., Nyers, P. \& Turner, B.S. (eds.) Citizenship between Past and Future, 81-91. London: Routledge.

Painter, J. 2002. Multilevel citizenship, identity and regions in contemporary Europe. Anderson, J. (ed.) Transnational Democracy: Political Spaces and Border Crossings, 93-110. London: Routledge.

Pateman, C. 1970. Participation and Democratic Theory. Cambridge: Cambridge University Press.

Pocock, J. G. A. 1998. The ideal of citizenship since classical times. Shafir, G. (ed.) The Citizenship Debates: A Reader, 31-42. Minneapolis: University of Minnesota Press. 
Rasmussen, C., \& Brown, M. 2002. Radical democratic citizenship: Amidst political theory. Isin, E.F. \& Turner, B.S. (eds.) Handbook of Citizenship Studies, 175188. London: Sage.

Roche, M. 2002. Social citizenship: Grounds of social change. Isin, E.F. \& Turner, B.S. (eds.) Handbook of Citizenship Studies, 69-86. London: Sage.

Samers, M. 2010. Migration. London: Routledge.

Sassen, S. 2002. Towards post-national and denationalized citizenship. Isin, E.F. \& Turner, B.S. (eds.) Handbook of Citizenship Studies, 277-291. London: Sage.

Saward, M. 2010. The Representative Claim. Oxford: Oxford University Press.

Schuck, P.H. 2002. Liberal citizenship. Isin, E.F. \& Turner, B.S. (eds.) Handbook of Citizenship Studies, 131-144. London: Sage.

Shachar, A (2009). The Birthright Lottery. Citizenship and Global Inequality. Cambridge: Harvard University Press.

Smith, M. J., \& Pangsapa, P. 2008. Environment and Citizenship: Integrating Justice, Responsibility and Civic Engagement. London: Zed.

Smith, R. M. 2002. Modern citizenship. Isin, E.F. \& Turner, B.S. (eds.) Handbook of Citizenship Studies, 105-115. London: Sage.

Soysal, Y. N. 1994. Limits of Citizenship: Migrants and Postnational Membership in Europe. Chicago: University of Chicago Press.

Standing, G. 2009. Work after Globalization: Building Occupational Citizenship. Cheltenham: Edward Elgar.

Taylor, C. 1994. Multiculturalism: Examining the Politics of Recognition. Princeton: Princeton University Press.

Taylor, G. 2010. The New Political Sociology: Power, Ideology and Identity in an Age of Complexity. Basingstoke: Palgrave Macmillan. 
Tharmalingam, S. 2011. Homeland Orientation of War-torn Diasporas: Remittances and Cultural Practices of Tamils and Somalis in Norway. (PhD), University of Oslo.

Tijsterman, S. 2014. Global and cosmopolitan citizenship. Van der Heijden, H.-A, (ed.) Handbook of Political Citizenship and Social Movements, 177-201. Cheltenham: Edward Elgar.

Tilly, C. \& Tarrow, S. 2007. Contentious Politics. Boulder: Paradigm.

Törnquist, O. 2009. Introduction: The problem is representation! Towards and Analytical Framework. Törnquist, O. Webster, N. \& Stokke, K. (eds.) Rethinking Popular Representation, 1-23. Basingstoke: Palgrave-Macmillan. Törnquist, O., Webster, N., \& Stokke, K. (eds.) 2009. Rethinking Popular Representation. Basingstoke: Palgrave-Macmillan.

Turner, B. S. 1986. Citizenship and Capitalism: The Debate over Reformism. London: Unwin Hyman.

Van der Heijden, H.-A. (ed.) 2014. Handbook of Political Citizenship and Social Movements. Cheltenham: Edward Elgar.

Vandenberg, A. (ed.) 2000. Citizenship and Democracy in a Global Era. New York: St. Martin's Press.

Vertovec, S. 2009. Transnationalism. London: Routledge.

Young, I.M. 1990. Justice and the Politics of Difference. Princeton: Princeton University Press.

Young, I.M. 1998. Polity and group difference: A critique of the ideal of universal citizenship. Shafir, G. (ed.) The Citizenship Debates, 263-290. Minneapolis: University of Minnesota Press. 


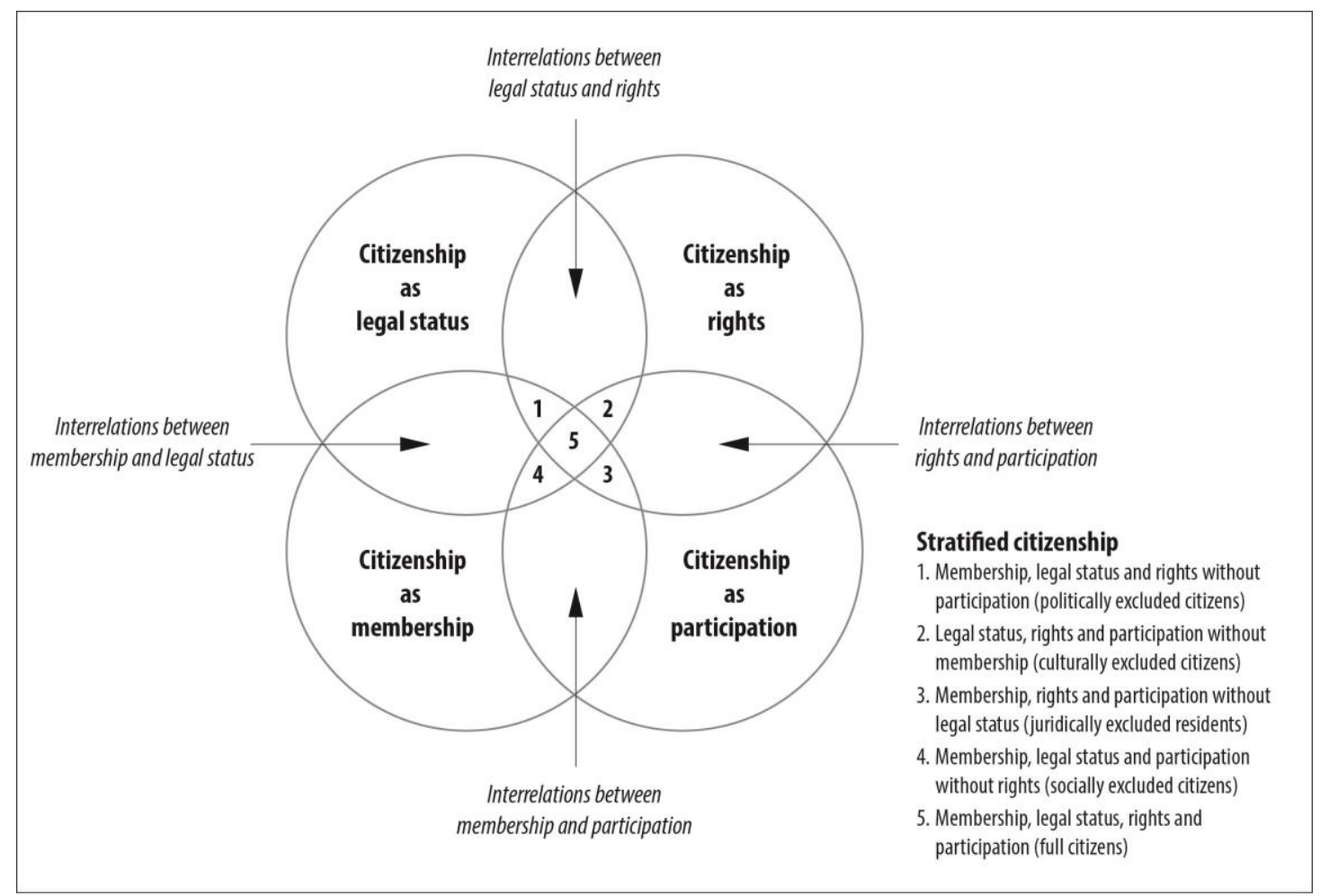

Figure 1. Dimensions and stratification of citizenship 


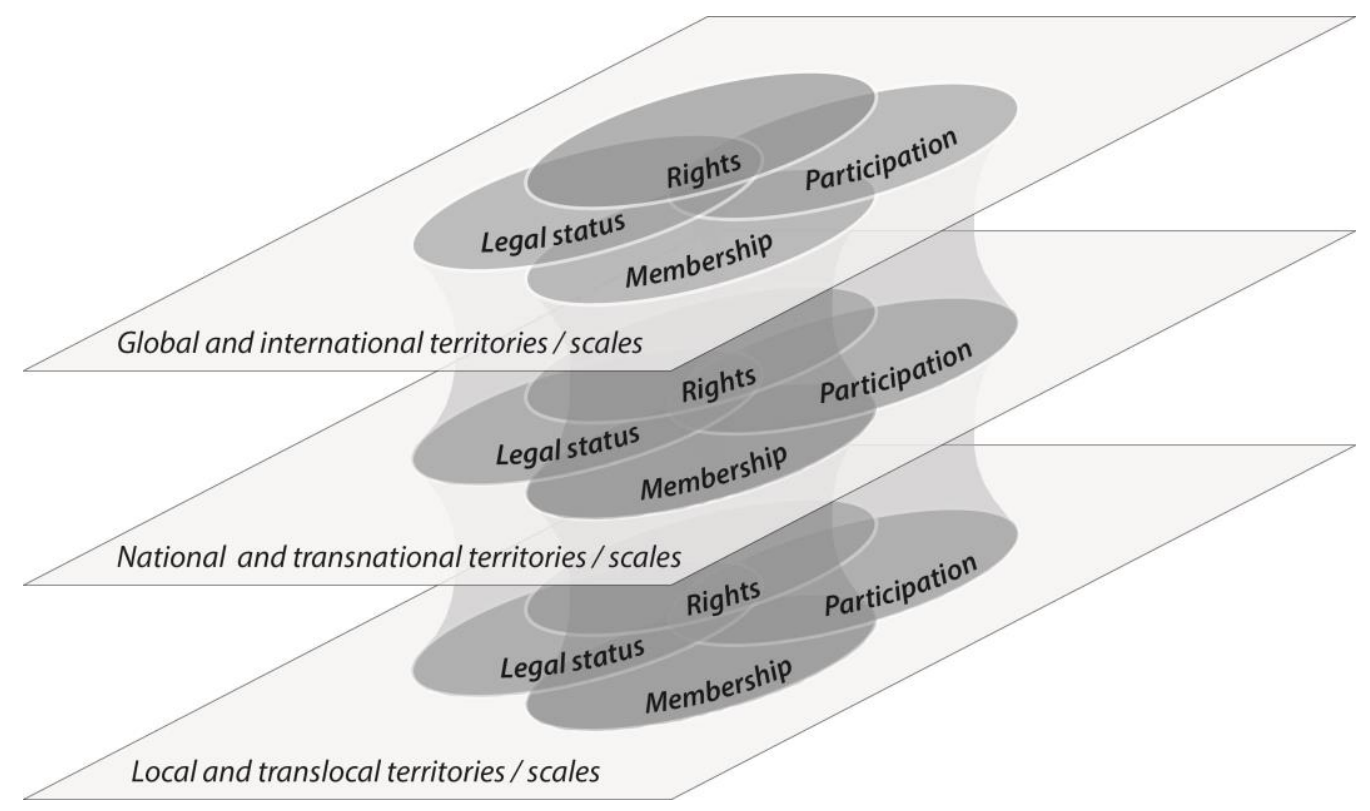

Figure 2. Multiple and relational scales and territories of citizenship 


\begin{tabular}{cccc}
$\begin{array}{c}\text { Forms } \\
\text { of } \\
\text { injustice }\end{array}$ & $\begin{array}{c}\text { Politics } \\
\text { of } \\
\text { justice }\end{array}$ & Affirmation & Transformation \\
\cline { 3 - 4 } Maldistribution & $\begin{array}{c}\text { Politics of } \\
\text { redistribution }\end{array}$ & $\begin{array}{c}\text { Liberal welfare } \\
\text { state }\end{array}$ & Socialism \\
Misrecognition & $\begin{array}{c}\text { Politics of } \\
\text { recognition }\end{array}$ & Multiculturalism & Deconstruction \\
Misrepresentation & $\begin{array}{c}\text { Politics of } \\
\text { representation }\end{array}$ & $\begin{array}{c}\text { Proportional } \\
\text { representation }\end{array}$ & $\begin{array}{l}\text { Substantive } \\
\text { democracy }\end{array}$ \\
\hline
\end{tabular}

Table 1. Forms of injustice and politics of justice (based on Fraser, 2009; Fraser \& Olson, 2008). 